ETNOGRAFANDO PATRIMÔNIOS: OS REFLEXOS DA FORMAÇÃO EM ANTROPOLOGIA E ARQUEOLOGIA NO PROCESSO DO INVENTÁRIO NACIONAL DE REFERÊNCIAS CULTURAIS /INRC - LIDAS CAMPEIRAS NA REGIÃO DE $B A G E ́ / R S$

ETNOGRAPHYING HERITAGES: REFLECTS OF THE TRAJECTORY IN ANTHROPOLOGY AND ARCHEOLOGY IN THE PROCESS OF INVENTÁRIO NACIONAL DE REFERENNCIAS CULTURAIS/ INRC - LIDAS CAMPEIRAS IN THE REGION OF $B A G \dot{E} / R S$

Liza Bilhalva

Marta Bonow Rodrigues

Como citar este artigo:

BILHALVA, Liza; RODRIGUES, Marta Bonow. Etnografando patrimônios: os reflexos da formação em Antropologia e Arqueologia no processo do Inventário Nacional de Referências Culturais /INRC - lidas campeiras na região de Bagé/RS. In: Cadernos do Lepaarq, v. XVI, n.32., p. 7-27, Jul-Dez. 2019. 


\title{
Etnografando patrimônios: os reflexos da formação em Antropologia e Arqueologia no processo do Inventário Nacional de Referências Culturais /INRC - lidas campeiras na região de Bagé/RS
}

\author{
Liza Bilhalva $^{\mathrm{a}}$ \\ Marta Bonow Rodrigues ${ }^{\mathrm{b}}$
}

Resumo: Este artigo tem como objetivo refletir sobre a influência da formação em Antropologia Social e Cultural/ Arqueologia no processo de produção e elaboração do Inventário Nacional de Referências Culturais (INRC) Lidas Campeiras* na Região de Bagé/RS. Procuramos apresentar essa experiência e apontar as contribuições que a formação acadêmica propiciou na pesquisa deste inventário, especialmente no que tange à categoria patrimônio, bem como a reciprocidade e a repercussão da metodologia INRC na formação que adquirimos e nas pesquisas que desenvolvemos durante a trajetória acadêmica..

\begin{abstract}
This article aims to reflect about the influence on the formation of Social and Cultural Anthropology/ Archeology in the process of production and writing of the Inventário Nacional de Referências Culturais (INRC) - Lidas Campeiras** in the Region of Bagé/RS. We look to present this experience and point out the contributions that the academic trajectory had make in the research of this inventory, especially in relation to the heritage category, as well as the reciprocity and its repercussion of the INRC methodology in the formation we build, and in the researches developed during the academic trajectory..
\end{abstract}

\section{Palavras Chave:}

Patrimônio, Método, Antropologia, Arqueologia, Formação Acadêmica, Interdisciplinaridade

\section{Keywords:}

Heritage, Method, Anthropology, Archeology, Academic Training, Interdisciplinarity

\footnotetext{
$\boldsymbol{a}$ Doutoranda do Programa de Pós-Graduação em Educação Ambiental da Universidade Federal do Rio Grande (FURG), Brasil; Mestra em Antropologia Social e Cultural pela Universidade Federal de Pelotas (UFPel), Brasil; Bacharela em Antropologia Social e Cultural pela Universidade Federal de Pelotas (UFPel), Brasil.

$\boldsymbol{b}$ Mestra em Antropologia - Área de Concentração em Arqueologia pela Universidade Federal de Pelotas (UFPel), Brasil; Bacharela em Antropologia - Linha de Formação em Arqueologia pela UFPel, Brasil.

* Lidas campeiras - categoria êmica - atividades exercidas pelos trabalhadores do campo envolvidos com pecuária no Rio Grande do Sul. Bagé é uma cidade localizada no sudoeste do estado do Rio Grande do Sul.

** Lidas Campeiras = Campeiras Handling, the labor of country men from de region of Brazilian Pampas - in the State of Rio Grande do Sul.
} 


\section{INTRODUÇÃO}

Para iniciar esta discussão, é necessário que façamos uma breve explanação sobre o que são as Lidas Campeiras: um conjunto de trabalhos exercidos no meio rural e que ultrapassam a categoria laboral para fazerem parte de um modo de vida, o campeiro. Essas lidas estão centradas na atividade do pastoreio, na produção pecuária de rebanhos de forma extensiva ${ }^{1}$ em regiões do Rio Grande do Sul, Uruguai e Argentina. São essas lidas, essa vida campeira, referências culturais de comunidades habitantes dos pampas sul-riograndenses, que são observadas e estudadas no processo do Inventário Nacional de Referências Culturais descrito a seguir.

O Inventário Nacional de Referências Culturais/INRC² - Lidas Campeiras na Região de Bagé/RS surge de uma demanda da Prefeitura Municipal de Bagé/RS, no âmbito do Programa de Aceleração do Crescimento/PAC das Cidades Históricas (Termo de Cooperação no 01/2010), do Governo Federal Brasileiro. Esta pesquisa foi acolhida e executada pela Universidade Federal de Pelotas, através do Departamento de Antropologia e Arqueologia e utilizou a metodologia de documentação de referências culturais do Instituto do Patrimônio Histórico e Artístico Nacional/IPHAN ${ }^{3}$, que tem como base a formação de equipe com profissionais das áreas de Antropologia e História ${ }^{4}$, permitindo a composição interdisciplinar na ampliação do grupo de trabalho.

Para este INRC, a equipe estava formada por profissionais e estudantes de antropologia, arqueologia, história, ciências sociais, geografia e arquitetura/urbanismo ${ }^{5}$, o que resultou em um trabalho com reflexões densas a respeito do tema do patrimônio e entrou em consonância com a indicação do IPHAN, voltando os olhares para a desconstrução de dicotomias entre cultura material e imaterial na produção do conhecimento (RIETH et al, 2013a, 2013b, 2013c; SILVA, 2014). Assim, há uma influência dessa interdisciplinaridade nos resultados desta pesquisa, bem como há o caminho contrário, com este trabalho permeando as formações de estudantes incluídos no processo.

Como estudantes, adentramos o mundo acadêmico com algumas perspectivas, porém sem nenhuma certeza. Dessa forma, este INRC, por abraçar diferentes disciplinas e proporcionar o contato entre pessoas de diversas áreas de pesquisa, além de propiciar um contato direto com a comunidade do meio campeiro, foi um elemento importante para a definição profissional de algumas e alguns membros do projeto. A forma como ocorreu a inserção de estudantes - pode-se dizer que todas/ os que buscaram a inclusão no projeto foram acolhidos/as, quando não haviam sido indicados/as previamente - e de profissionais (professoras e professores universitários) fez com que acadêmicas/os em formação direcionassem suas preferências para seguir sua profissão. O tema do patrimônio apresentou-se com esse perfil múltiplo através do projeto: o Inventário influenciou a equipe e, em contrapartida, a equipe, com seus olhares distintos, configurou uma pesquisa interdisciplinar e satisfatória.

\footnotetext{
${ }^{1}$ Criação de animais de produção, especialmente bovinos, na qual os rebanhos são mantidos em pastagens naturais ou exóticas, sem estarem em espaços confinados.

2 INRC é um instrumento de conhecimento de bens culturais de qualquer natureza. Fazer um inventário é fazer um levantamento, uma listagem descritiva dos bens culturais que remetem às referências culturais - materiais e imateriais - de um lugar ou grupo. (IPHAN, 2012).

3 Órgão que também financiou a pesquisa.

${ }^{4}$ No mínimo um/a profissional de cada uma dessas duas áreas é uma recomendação do IPHAN.

5 A pesquisa de campo ocorreu entre 2010 e 2013, com financiamento e metodologia do IPHAN. Compõem a equipe desse INRC: Prof Flávia Rieth - Coord.; Pesquisadoras/es: Marília Kosby, Liza Bilhalva, Marta Rodrigues, Pablo Dobke, Daniel Lima; Consultoras/es: Cláudia Magni (Imagem), Fernando Camargo (História), Erika Collischonn (Geografia), Karen Mello (Arquitetura/Urbanismo); IPHAN: Beatriz Freire e Marcos Benedetti.
} 
O primeiro passo na elaboração desse Inventário ocorreu através de leituras - algumas partindo de disciplinas no curso de Graduação em Antropologia da UFPel, outras apresentadas pelos membros da equipe - sobre patrimônio material e imaterial, construção de conhecimento antropológico, arqueológico e histórico, cultura campeira e pecuária extensiva. Com isso, buscamos a preparação para o trabalho de campo, entendendo que apenas a etnografia poderia nos levar à compreensão das dimensões semânticas que a categoria patrimônio assume nesse contexto cultural. Cabe ressaltar que havia a preocupação de atentar sempre para as relações entre materialidade e imaterialidade, entre pessoas, animais, lugares, artefatos, objetos, paisagem, pois esses elementos estão absolutamente interdependentes nessa cultura e a formação do bacharelado ao qual a maioria da equipe estava vinculada traz a interface entre Antropologia e Arqueologia.

Para o trabalho etnográfico seguimos a metodologia indicada para INRCs (IPHAN, 2000) que compreende a descrição minuciosa em fichas de identificação do sítio e localidades, da história de interlocutores/as, e de bens culturais ${ }^{6}$. A investigação envolveu cidades do pampa sul-riograndense ${ }^{7}$ o qual centra sua economia na produção de rebanhos, especialmente bovinos, ovinos e equinos (RIETH et al, 2013a, 2013b, 2013c). Estávamos diante de uma rede heterogênea (LATOUR, 2009) composta por humanos e não humanos e pelas práticas atinentes à atividade pecuária. Essa rede se configura a partir de significações locais próprias, cuja especificidade está na relação entre a diversidade biológica e a cultural, uma interdependência evidente nos sistemas pastoris (CARNEIRO DA CUNHA, 2005), e as lidas campeiras se apresentavam como um entrelaçamento de trabalho e modo de vida, em que as práticas são percebidas como um saber viver e se relacionar com o ambiente. A categoria trabalho, nesse ínterim, parece ter seu valor potencializado, consequência do processo histórico de desenvolvimento associado à modernização (SILVA, 2014).

$\mathrm{Na}$ observação das práticas culturais percebemos que as lidas campeiras, embora sofrendo transformações ao longo do tempo, expunham aspectos ideais e valorativos desse modo de vida, colocando em relação pessoas e "coisas" - incluindo a própria natureza e o espaço (SANTOS, 2002) -, conformando subjetividades e elegendo símbolos, os quais muitas vezes são percebidos como o próprio patrimônio desses grupos culturais (SILVA, 2014). Esses símbolos compartilhados têm a capacidade de expressar de forma sintética e afetiva uma relação entre ideias e valores e estão conectados à identidade dos sujeitos, entendida como uma construção dinâmica social e ideológica, com valores prévios (normalmente subsidiários a algum interesse) e com uma certa fixação e perduração no tempo (PRATS, 1998).

Todas as pessoas entrevistadas no âmbito da pesquisa ${ }^{8}$ estão nas mais diferentes atividades associadas à pecuária, $\mathrm{e}$ encontram nas lidas campeiras o seu patrimônio cultural, uma vez que entendem tais bens como representativos de seu grupo de pertencimento (SILVA, 2014). Estávamos, portanto, diante de um grupo rural compartilhando um modo de vida, no qual o trabalho e a mão de obra são escassos, as políticas públicas não chegam e as tecnologias substituem a mão humana arrastando

\footnotetext{
${ }^{6}$ Os dados estão inseridos nas seguintes fichas: Identificação do Sítio; Ident. de Localidades; Bibliografia; Ident. de Ofícios e Modos de Fazer; Ident. de Celebrações; Contatos; Questionários de Ident.de Ofícios e Modos de Fazer; Reg. Audiovisual.

${ }^{7}$ A denominação pampa não foi configurada somente conforme delimitações geográficas, mas referida a partir dos agenciamentos de relações que se estabelecem entre paisagens, homens, animais, ofícios e utensílios, na configuração de um modo de vida "campeiro" (sua construção, abandono e perpetuação).

${ }^{8}$ Um total de 69 pessoas nas Fichas de Contatos (RIETH et al., 2013b). A pesquisa acompanhou o dia-a-dia de alguns desses contatos (conforme fichas de Ofícios e Modos de fazer - RIETH et al., 2013a), enquanto outros foram entrevistados como parte da rede indicada, porém sem estarem obrigatoriamente na atuação do campo. Salientamos que, desses 69 contatos, apenas 13 eram mulheres (18\%, aproximadamente), sendo que na atuação das lidas, (fichas de Ofícios e Modos de Fazer) as mulheres aparecem ainda menos - consequência provável do "seguir a rede", já que o campo se apresenta, para nós, como majoritariamente masculino, invisibilizando as mulheres. Esta questão está sendo acompanhada nas novas fases do Inventário, desde 2014, com a ampliação da pesquisa e a inserção de cidades com uma grande quantidade de pequenas propriedades, que se configuram de outro formato, onde a participação das mulheres é mais visível.
} 
comunidades e indivíduos para outros contextos, especialmente urbanos (SILVA, 2013; SILVA, 2014).

Essas mudanças traziam consigo a ideia de ruína e de desaparecimento da base fundante e necessária para a reprodução social; ainda que a equipe pudesse observar as transformações das práticas ao longo do tempo, para muitas pessoas desses grupos, essas alterações, típicas da contemporaneidade no mundo globalizado, são compreendidas como perdas: "Isso [lidas campeiras] faz parte da nossa cultura, vivemos isso, e algumas coisas estão desaparecendo. As pessoas estão indo embora do campo, não tem valorização, precisamos fazer alguma coisa antes que seja tarde demais" (Flávia Blanco - informação pessoal. Aceguá, 2013).

Para esses grupos, a equipe do INRC representava a política pública com um interesse legítimo em refletir conjuntamente sobre o que representaria o patrimônio a ser preservado e salvaguardado nos termos indicados pela política do IPHAN (SILVA, 2014). Dessa maneira, foi possível o acesso e a participação da vida cotidiana desses coletivos, vivenciando e experienciando juntamente com as/os interlocutoras/es (WAGNER, 2010) as práticas e saberes desse grupo cultural.

Evidenciou-se que o processo de invenção, construção e transformação da cultura campeira ocorre através das relações entre os diferentes agentes humanos e não humanos presentes na estrutura das mais diferentes dimensões de sua existência, ou seja, tal bem é simultaneamente de natureza econômica, moral, religiosa, mágica, política, jurídica, estética, psicológica e fisiológica (GONÇALVES, 2003). Esse modo de vida e práticas compartilhadas apareciam como um conjunto inseparável de materialidade e imaterialidade.

A interdisciplinaridade trazida pela equipe permitiu olhares direcionados a vários elementos constituintes dos sujeitos campeiros que são fundamentais para a valorização dessa cultura, tão fortemente balizada no ambiente e nos artefatos especialmente produzidos e mantidos para as práticas cotidianas (BILHALVA \& RODRIGUES, 2017).

Para o desempenho, vivências e experiências nas atividades da lida campeira, é necessário saber fazer, conhecer e aplicar o uso de artefatos específicos. Assim, dentro do INRC, enfatizar na cultura material é dialogar com o conceito antropológico de cultura, de modo a perceber a agência dos objetos e artefatos na lida campeira, bem como as potencialidades simbólicas de sua plasticidade9 (BILHALVA \& RODRIGUES, 2017, p. 116-117).

Essa visão foi possível principalmente pela formação aproximada entre Antropologia e Arqueologia. Em retorno, a metodologia de Inventário Cultural do IPHAN permitiu, através das descrições minuciosas de todos os elementos, a observação de sutilezas entremeadas na extração das matérias-primas, confecção e utilização dos artefatos nas lidas. Há uma cultura material própria dessas atividades e, ainda que alguns materiais entendidos como originais pudessem ser substituídos por outros $^{10}$, os artefatos são mantidos, pois fazem parte do todo dessa cultura campeira, são parte da identidade desses coletivos e também atuam na construção dos indivíduos (BILHALVA \& RODRIGUES, 2017).

Observando esses elementos e entendendo as fronteiras fluídas entre material e imaterial, percebemo-nos diante de

\footnotetext{
${ }^{9}$ Lúcia Hussak van Velthem (2007), em "Farinha, casas de farinha e objetos familiares em Cruzeiro do Sul - Acre", aponta para a importância de a perspectiva antropológica extrapolar o utilitarismo dos objetos e artefatos, tomando-os como agentes capazes de constituírem sistemas de relações sociais entre si e os seres humanos com quem trabalham. Desta forma, são agregados aos objetos materiais, atributos genealógicos, históricos e de intencionalidade.

${ }^{10}$ Um exemplo é o laço: originalmente e preferencialmente, o laço para contenção dos animais no campo é feito em couro, normalmente confeccionado de forma artesanal. No entanto, são aceitos pelos trabalhadores laços industriais feitos em materiais sintéticos, como o nylon, por exemplo. Cabe salientar que esses laços sintéticos nem sempre são os mais apropriados para contenção, pois, segundo informações dos interlocutores, ele pode "queimar" a pele do animal, causando ferimentos.
} 
um potencial patrimônio intangível (SILVA, 2014). Dentro das análises de campo e pensando sempre em uma produção de conhecimento conjunta com a comunidade, apontamos para o IPHAN sete bens culturais, indicados pelo grupo sociocultural, que representariam o patrimônio imaterial da região de Bagé/RS: o ofício do pastoreio, da esquila, da doma, da tropeada, do guasqueiro, do alambrador e da lida caseira (RIETH, et al., 2013a, 2013b, 2013c.):

A esquila é a tosa dos ovinos, a retirada das lãs; a doma, a preparação dos cavalos para que possam ser montados e utilizados em atividades diversas; o tropeirismo é o transporte dos rebanhos por terra, conduzidos por campeiros a cavalo; a lida caseira é a manutenção doméstica e cotidiana da propriedade rural, no entorno das sedes - casas e galpões, é a lida atribuída a homens e/ou mulheres, no universo da pesquisa; a feitura dos aramados ou alambrados (termo em espanhol, porém muito utilizado na região do pampa sul-riograndense) é a atividade vinculada à construção e manutenção das cercas de arame que contornam as propriedades e suas divisões internas; o guasqueiro é aquele que produz artefatos e utensílios em couro, tanto como artesanato, quanto para o uso nas lidas; o pastoreio é a lida direta com os rebanhos (BILHALVA \& RODRIGUES, 2017, p. 115-116).

O processo de pesquisa com essa perspectiva de retroalimentação - formação acadêmica interdisciplinar influenciando a pesquisa do INRC e vice-versa - foi fundamental para o entendimento de elementos básicos na construção do conhecimento, sendo um dos mais evidentes aquilo que Roy Wagner (2010) aponta: "somos todos antropólogos". Com os diferentes olhares, foi possível discutir sobre uma análise ampla da noção de cultura e de patrimônio (GONÇALVES, 2007). À medida que inventamos a cultura do outro, conectando suas práticas e saberes à metodologia INRC (ou nos moldes de nossa própria cultura), interlocutores/as inventavam, concomitantemente, a sua cultura. Equipe de pesquisa e grupos campeiros criavam elos e pontes no esforço de apreender e inventar as diferentes culturas ali postas. Segundo Roy Wagner,

Ela [a invenção da cultura] ocorre toda vez e onde quer que algum conjunto de convenções "alienígena" ou "estrangeiro" seja posto em relação com o do sujeito (WAGNER, 2010: 39). [...] Invenção, portanto, é cultura, e pode ser útil conceber todos os seres humanos, onde quer que estejam, como "pesquisadores de campo" que controlam o choque cultural da experiência cotidiana mediante todo tipo de "regras", tradições e fatos imaginados e construídos (WAGNER, 2010, p. 75).

A interdisciplinaridade, a formação acadêmica em andamento e a metodologia e preceitos de pesquisa do IPHAN desencadearam o surgimento de projetos de TCC, dissertações de mestrado e teses de doutorado. Refletir sobre esses desdobramentos, como frutos e, ao mesmo tempo parte da reflexão e desenvolvimento do processo investigativo do INRC é fundamental para pensarmos sobre áreas de atuação profissional, interação entre academia e trabalho de campo e, especialmente, nesse caso, na formação em Antropologia e Arqueologia frente a políticas de patrimônio.

\section{Apontamentos-chave sobre Patrimonial Cultural: a preparação para o campo}

Em se tratando de um Inventário de Bem Patrimonial, foram imprescindíveis as leituras e discussões que pudessem dar conta da complexidade de compreensões que envolvem o conceito de patrimônio cultural. Seguimos alguns textos como base para a ampliação de nossas próprias ideias de patrimônio.

Percebemos que deveríamos ter cuidado para que não naturalizássemos as nossas próprias representações sobre pa- 
trimônio entendendo que este é uma categoria de pensamento bastante familiar aos conceitos modernos do mundo ocidental e vinculado às formações dos Estados Nacionais, porém, não o único. Para que a diversidade cultural esteja contemplada nos processos de documentação dos bens, é necessário observar as diversas dimensões semânticas que a categoria patrimônio assume entre diferentes grupos, um dos pontos de interesse da tradição antropológica (GONÇALVES, 2003). Refletir sobre essas diversas formas de compreensão sobre a categoria é compreender que patrimônio cultural pode ser uma invenção como capacidade de gerar discursos sobre a realidade (discursos de poder) e, ao mesmo tempo, uma construção social - como a via de legitimar/assimilar socialmente esses discursos (PRATS, 1998).

E pensando a patrimonialização como política preservacionista do Estado atrelada às percepções de passado-presente, patrimônio pode ser o que Poulot (2008) chamaria de distinção entre "o que é verdadeiramente herdado e o que é (re) construído, ou entre as ficções sinceras e as invenções desonestas, porém, mais amplamente se trata de questionar a produção e o consumo de evidência patrimonial ela própria, ao mesmo tempo imaginária e instituição.” (POULOT, 2008, p. 39-40).

Essa trajetória da política de preservação do patrimônio cultural no contexto mundial sempre esteve atrelada à Antropologia. Não por acaso são antropólogas e antropólogos muitos dos que estiveram e estão à frente dos projetos de renovação e ampliação da categoria patrimônio. É importante não esquecer que a própria Antropologia nasce nos museus e é marcada pela ideia de preservação desde seu início, quando os primeiros pesquisadores da disciplina coletavam objetos e documentos em suas pesquisas de campo e depois os armazenavam nos laboratórios (FILHO \& ABREU, 2007).

Os caminhos que a categoria patrimônio vem percorrendo, portanto, parecem seguir a moderna concepção antropológica de cultura, na medida em que deixou de eleger para preservação o patrimônio de "pedra e cal” e passou a "desmaterializar” a cultura, preocupando-se com o patrimônio intangível (GONÇALVES, 2003; 2007).

Salientamos que o intangível/imaterial que abrange as ações humanas não está isolado do mundo material, pois todas as culturas são intermeadas e intermediadas por artefatos e objetos - aspecto bastante relevante na cultura campeira, como citado anteriormente, a qual se apresentou absolutamente dependente, em maior ou menor grau, dessa materialidade. Por dependente entendemos que há tanto a necessidade prática quanto simbólica do uso de determinados artefatos e objetos para a perpetuação do modo de vida campeiro (BILHALVA \& RODRIGUES, 2017).

\section{Entendendo percursos de registros patrimoniais no Brasil e a metodologia para a elaboração do INRC Lidas Campeiras}

As medidas adotadas para salvaguardar os bens culturais brasileiros reportam-se aos anos 1930, quando há disposições legais sobre a evasão de obras de artes de território nacional e questões sobre o direito à propriedade em cidades históricas mineiras, bem como a submissão da propriedade privada ao interesse coletivo sob a ingerência do Estado (FILHO \& ABREU, 2007; FUNARI \& PELEGRINI, 2009). Nesta época, o anteprojeto de Mário de Andrade para institucionalização da preservação de bens culturais já apresentava uma visão mais culturalista e antropológica, privilegiando a perspectiva intangível de patrimônio. No entanto, a proposta acatada foi protagonizada por Rodrigo de Mello Franco de Andrade, primeiro diretor do Serviço do Patrimônio Histórico e Artístico Nacional/SPHAN (atual IPHAN) que beneficiava os aspectos materiais dos bens (FREIRE, 2005; FUNARI \& PELEGRINI, 2009).

O modo de perceber o patrimônio altera-se apenas nos anos 1960, quando sítios arqueológicos - bens de interesse científico e/ou ambiental - são reconhecidos como patrimônios da União (FUNARI \& PELEGRINI, 2009). Mas é apenas nos anos 1970/80 que o campo do patrimônio se aproxima das Ciências Sociais e tem sua noção ampliada passando a se preocupar 
com manifestações coletivas como referências culturais (FREIRE, 2005).

Cabe lembrar que até o ano 2000, o IPHAN não dispunha de instrumento adequado para preservação de processos dinâmicos; a partir desta data, após debates interdisciplinares sobre o conceito de bem cultural imaterial e sobre trâmites para seu reconhecimento, há a instauração do Registro de Bens Imateriais, utilizado para a documentação e produção de conhecimento para preservação desses bens (FREIRE, 2005; FUNARI \& PELEGRINI, 2009).

O IPHAN desenvolve, então, uma metodologia singular para documentação de bens: o INRC, o qual visa reunir informações sobre determinado bem cultural e apreender os sentidos e significados que lhe são atribuídos por grupos e coletividades. Para uma manifestação cultural concorrer ao registro, é necessário um amplo dossiê com pesquisas consistentes, descrições detalhadas e justificativas sobre as razões do pedido de patrimonialização (FREIRE, 2005). Esse registro ocorre por meio da inclusão, após análise de todos os elementos e aprovação por comissão indicada pelo Conselho Consultivo do IPHAN, desse bem cultural em um dos 4 livros: Livro de Registro dos Saberes, Livro de Registro das Celebrações, Livro de Registros das Formas de Expressão e Livro de Registros dos Lugares (IPHAN, 2017).

O INRC prevê três níveis sucessivos de aproximação: 1) levantamento preliminar; 2) identificação do bem; 3) documentação (FREIRE, 2005). Em todas as fases, a metodologia consta do preenchimento de fichas específicas para cada fim; para as Lidas Campeiras de Bagé/RS, foram aplicadas: ficha de sítio, de localidade, de contatos, de entrevistas, de ofícios e modos de fazer, de celebrações, de bibliografia e de registros audiovisuais (RIETH et al, 2013a, 2013b, 2013c).

As fichas possibilitam encontrar, tornar conhecidos e identificar os bens culturais. "O uso desses procedimentos metodológicos, como instrumento de ação institucional, produzirá informações que, espera-se, realimentarão as políticas de patrimônio.” (IPHAN, 2000). Para isso, "a solicitação do Registro deve ser feita por instituições do Ministério da Cultura e suas vinculadas, por Secretarias Estaduais, Municipais e do Distrito Federal, pelas sociedades civis e associações civis" (FREIRE, 2005, p.17).

Os estudos para a construção desse processo podem ser realizados em parceria com instituições públicas e privadas e é necessária a concordância do grupo detentor das práticas a serem documentadas, sendo fundamental a responsabilidade social de pesquisadores (as) e técnicos (as) (FREIRE, 2005).

Com esses princípios norteadores, a equipe do INRC Lidas Campeiras na Região de Bagé/RS inicia a pesquisa em 2010, e em 2013, entrega o Relatório Final, completando as três fases anteriormente citadas.

\section{Entre fichas e formações}

A antropologia estuda o fenômeno do homem - a mente do homem, seu corpo, sua evolução, origens, instrumentos, arte ou grupos, não simplesmente em si mesmos, mas como elementos ou aspectos de um padrão geral ou de um todo (WAGNER, 2010, p. 27).

Conforme já apontado anteriormente, percebemos ao longo do processo de pesquisa e elaboração do relatório que a materialidade não poderia ser deixada de lado nas observações sobre as lidas campeiras. Sendo esta investigação executada através do Departamento de Antropologia e Arqueologia da UFPel, que se preocupa na aproximação entre essas duas áreas disciplinares, foi impossível excluir um olhar arqueológico que tratasse de patrimônio durante os anos do trabalho. Assim, os objetos e artefatos aparecem como parte fundamental e fundante do modo de vida campeiro na região do pampa sul-riograndense. Seguindo a metodologia do IPHAN, os objetos tiveram um espaço de visibilidade bastante destacado no relatório final, composto pelas fichas já citadas. 
Outro ponto importante diz respeito à quantidade de trabalhos acadêmicos produzidos como desdobramentos deste INRC: logo após a finalização da pesquisa e entrega do relatório, havia 1 projeto de doutorado, 3 projetos de mestrado, e 1 projeto de conclusão de curso em andamento ${ }^{11}$ - todos já defendidos. Atualmente, existem outras pesquisas acadêmicas em andamento, e o INRC das Lidas Campeiras está em processo de ampliação do campo e em fase de análise junto ao IPHAN.

A proposta demandada pelos três níveis de aproximação da metodologia INRC - levantamento preliminar, identificação e documentação - refere-se a problemas que não se limitam a disciplinas específicas. Dessa forma, a pesquisa impõe um esforço de criatividade e flexibilidade intelectual que resulta na permeabilidade das fronteiras entre modelos teóricos inerentes a diferentes especialidades: História, Antropologia Social e Cultural, Arqueologia, Geografia, Urbanismo e Sociologia, através de seus distintos lugares de fala, contribuíram para o conhecimento ampliado do bem investigado. A etnografia, levando em conta o cuidado em contemplar esse trânsito entre disciplinas, foi a base de todo o trabalho, buscando compreender as complexas relações existentes entre a história do grupo cultural, as estruturas físicas e materiais, os aspectos geográficos, sociológicos e os valores culturais.

As fichas que integram a metodologia do INRC (IPHAN, 2000, p. 39-155), conduziram à necessidade de explorar todos os aspectos possíveis da cultura campeira do pampa sul-riograndense. "Inventariar algo é encontrar, de forma exaustiva e sistemática, coerente com determinados critérios de inclusão e exclusão, os elementos que deverão constituir o inventário" (SILVA, 2014). Por meio do inventário, visava-se inserir as Lidas Campeiras no Livro dos Saberes e, com isso, tínhamos a tarefa de localizar, pesquisar e descrever os ofícios associados a esse bem cultural.

As fichas podem (e devem) ser utilizadas de forma a extrapolar a descrição somente do que os (as) interlocutores (as) falam. As fichas, na sua totalidade, demandam descrever o que as pessoas fazem, como fazem, com o que fazem e onde fazem, destacando a importância dos artefatos utilizados nas atividades, os espaços e a paisagem em que as mesmas são desenvolvidas, a história dos lugares e suas transformações, a alimentação, as bebidas e as roupas associadas, bem como as músicas e festas que a lida campeira, através de seus vários ofícios, abrange.

Assim, as fichas nos orientaram no caminho em que as redes de interlocutores (as) nos conduziram. Associado ao olhar treinado que nossa formação nos imprimiu, passamos a "olhar, ouvir e escrever" (CARDOSO DE OLIVEIRA, 2006) a cultura e/ou as práticas dos interlocutores e interlocutoras na sua totalidade, de forma a perceber a lida campeira presente na estrutura de diferentes dimensões de sua existência, configurando-se como um modo de vida e não apenas um trabalho para subsistência econômica (GONÇALVES, 2005; RIETH, RODRIGUES \& SILVA, 2015).

Quando delimitamos o sítio da pesquisa e começamos a seguir a rede de interlocutores (as), passamos a conviver com essas pessoas, acompanhando suas vidas diárias. Deparamo-nos, então, com uma extensão de significados que a lida campeira imprime nas pessoas e nas coisas que os rodeiam; ela está presente no trabalho, nas vestimentas, nos hábitos alimentares, na decoração das casas, na arte, na música, na poesia, nas danças, na religiosidade (a imagem de São Jorge em seu cavalo é comum nas casas, em formato de estátua, quadro, santinhos), nas festas locais, e consequentemente na política e nas leis.

A lida campeira, portanto, se constitui em cada ato da vida dessas pessoas, e por isso pode ser considerada como Referência Cultural, partindo de um todo que é o modo de vida, conforme os termos propostos pelo IPHAN:

\footnotetext{
${ }^{11}$ KOSBY, Marília F. Alma-caroço: Peregrinações com cabras negras pelo extremo sul do Brasil. 2018. Tese (Doutorado em Antropologia Social) - Instituto de Filosofia e Ciências Humanas, UFRGS, 2018. SILVA, Liza B. M. Entre lidas: Um estudo etnográfico sobre masculinidade, memória e trabalho campeiro nas cidades de Pelotas e Bagé, RS. 2014. Dissertação (Mestrado em Antropologia) - Universidade Federal de Pelotas, 2014.;

LIMA, Daniel V. "Cada doma é um livro": a relação entre humanos e cavalos no pampa sul-rio-grandense. 2015. Dissertação (Mestrado em Antropologia) - Universidade Federal de Pelotas, 2015.; BARRETO, Eric S. B. “Por dez vacas com cria eu não troco meu cachorro”: As relações entre homens e cães nas atividades pastoris do pampa brasileiro. 2015. Dissertação (Mestrado em Antropologia) - Universidade Federal de Pelotas, 2015.
} 
[…] são paisagens naturais, edificações, artes, ofícios, formas de expressão e modos de fazer. São as festas, e os lugares a que a memória e a vida social atribuem sentido diferenciado: as mais belas, as mais lembradas, as mais queridas. São fatos, atividades e objetos que mobilizam a gente mais próxima e que reaproximam os que estão longe, para que se reviva o sentimento de participar e de pertencer a um grupo e a um lugar. Em suma, referências são objetos, práticas e lugares apropriados pela cultura na construção de sentido de identidade (IPHAN, 2000, p. 29).

A formação da maioria da equipe - Antropologia - estava em consonância com a perspectiva adotada na política de Salvaguarda do Patrimônio Imaterial e, sobretudo, na metodologia INRC. Os três atos cognitivos apontados por Cardoso de Oliveira (2006), olhar, ouvir e escrever, estão marcados pela nossa inserção na disciplina antropológica. No olhar e ouvir "disciplinados", apuramos nossa percepção sobre o campo, e no escrever, exercitamos nosso pensamento como produtor de um discurso voltado à construção da teoria cultural e social. Este terceiro ato ocorre concomitante com a aprendizagem do preenchimento das fichas do INRC.

Ao passo que a cultura investigada se tornava visível para nós, aprendíamos também a inserir a descrição desse modo de vida nas fichas. As fichas eram "abertas" (termo que a equipe usava para iniciar as descrições dos bens, dos lugares, das celebrações e das edificações) e a partir de então, uma série de cruzamentos interdisciplinares surgiam, entre a rede de interlocutores (as) e entre as diferentes temporalidades que atravessam os sujeitos e seus saberes. Conforme conversávamos com um interlocutor, logo surgia uma indicação de outros interlocutores especializados em uma ou outra atividade, que forma o conjunto das lidas, como pode ser acompanhado nas imagens do trabalho de campo a seguir (figuras 1, 2, 3 e 4).

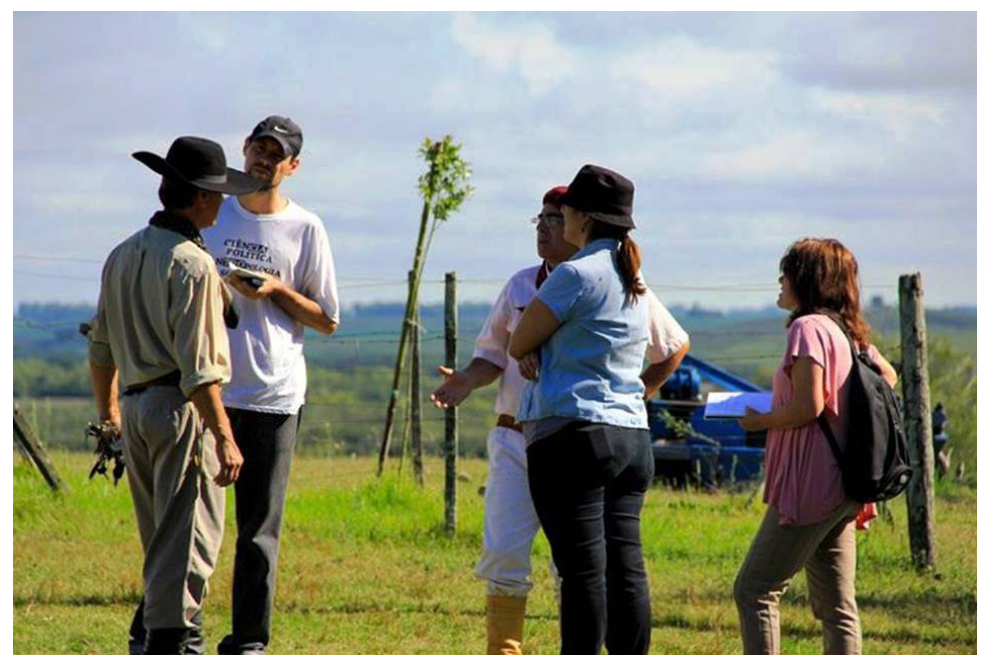

Figura 1 - Entrevista com interlocutor, Minga Blanco, proprietário rural e campeiro - Aceguá/RS. Foto: Acervo INRC Lidas Campeiras da Região de Bagé/RS (2012). 


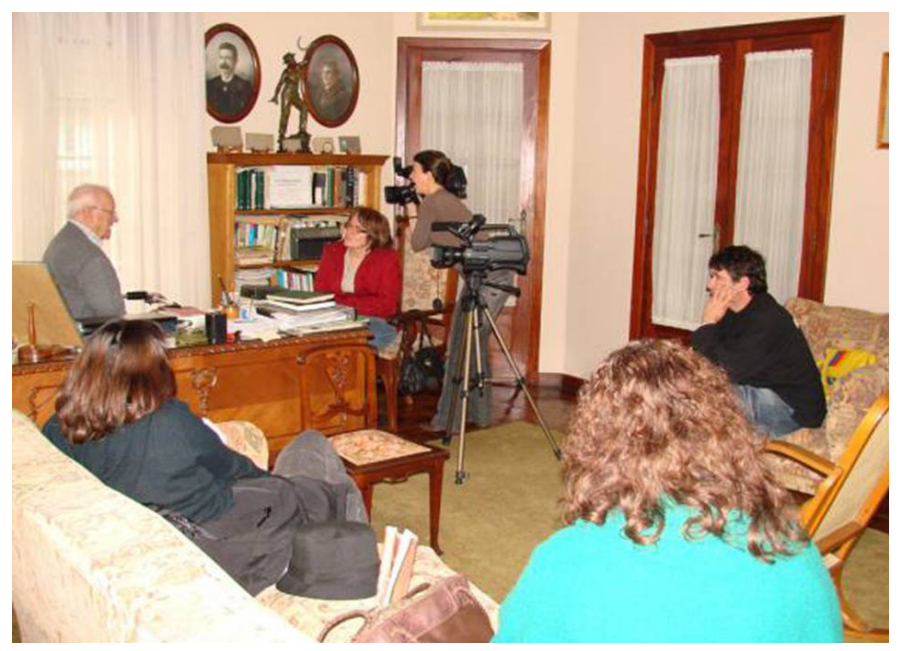

Figura 2 - Entrevista com o interlocutor Nilo Romero (in memorian), proprietário rural e introdutor do método de pastoreio Voisin para bovinos no Rio Grande do Sul - Bagé/RS. Foto: Acervo INRC Lidas Campeiras da Região de Bagé/ RS (2011).

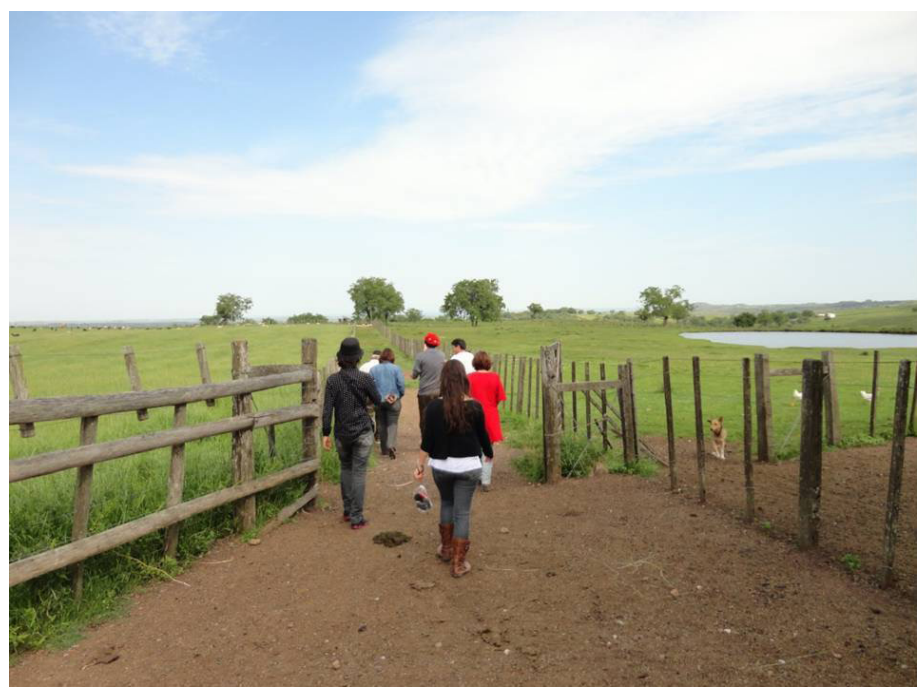

Figura 3 - Entrevista com Sr. Edemar (in memorian), pequeno produtor em Bagé/RS - o interlocutor leva a equipe para conhecer sua propriedade que se dedica principalmente à criação de ovinos. Foto: Acervo INRC Lidas Campeiras da Região de Bagé/RS (2011). 


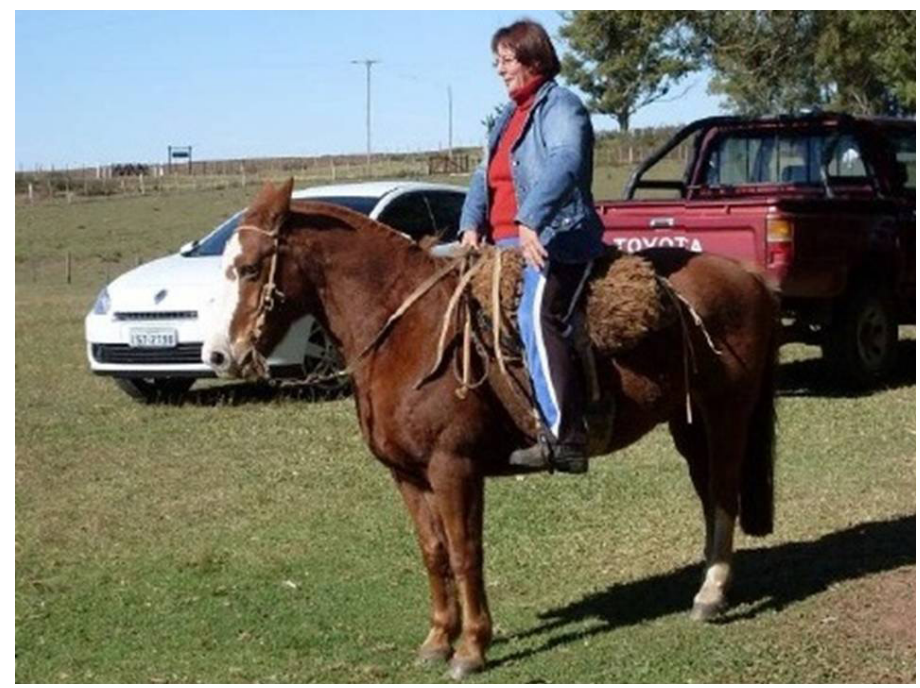

Figura 4 - A interlocutora Sônia Carlota Cabreira Garibaldi, pequena proprietária rural, produtora de gado bovino e ovino - Hulha Negra/RS. Foto: Acervo INRC Lidas Campeiras da Região de Bagé/RS (2012).

Concomitantemente, estávamos em campo e produzindo os textos nas fichas: estabelecíamos o contato, experienciávamos a cultura campeira, nos apropriávamos das fichas e escrevíamos nas mesmas a descrição dos bens. Esse processo não foi imediato, aprendemos a trabalhar com o modelo metodológico do INRC no decorrer da pesquisa. Essa forma de escrever não era o comumente realizado nas etnografias acadêmicas, nas quais há uma liberdade de escrita fluída. As fichas, inicialmente, nos pareceram fechadas, difíceis de abrangerem o todo que a etnografia propicia.

No entanto, foi exatamente esse processo de aprendizado e as características das fichas que permitiu nos disciplinarmos no campo e atentarmos para a cultura material, como costumamos atentar para as relações entre sujeitos, estrutura e sistemas simbólicos. Nesse tipo de formação, fomos influenciadas (os) pela tradição boasiana - four fields (BOAS, 2005), muito presente na nossa vida acadêmica, evidenciando o estudo de objetos materiais e técnicas dentro das culturas, dos quais a disciplina antropológica tentou se afastar ao longo do século XX, desmaterializando as formulações em favor de noções mais abstratas (GONÇALVES, 2005).

Para refletirmos sobre cultura/patrimônio precisamos falar sobre sua dimensão material, e as fichas do INRC nos direcionavam para isso, bem como nossas formações no âmbito do Departamento de Antropologia e Arqueologia/UFPel. É importante considerar que Patrimônio trata de uma categoria ambígua, pois transita entre o material e o imaterial, os quais aparecem de modo indistinto nos limites dessa categoria. A noção de patrimônio cultural, desse modo, enquanto categoria do entendimento humano, na verdade rematerializa a noção de "cultura".

Durante o processo de pesquisa, deparamo-nos com artefatos característicos das lidas campeiras e fundamentais para o desempenho das atividades. Esses artefatos, em sua maioria, são confeccionados por artesãos especializados. - os guasqueiros. 


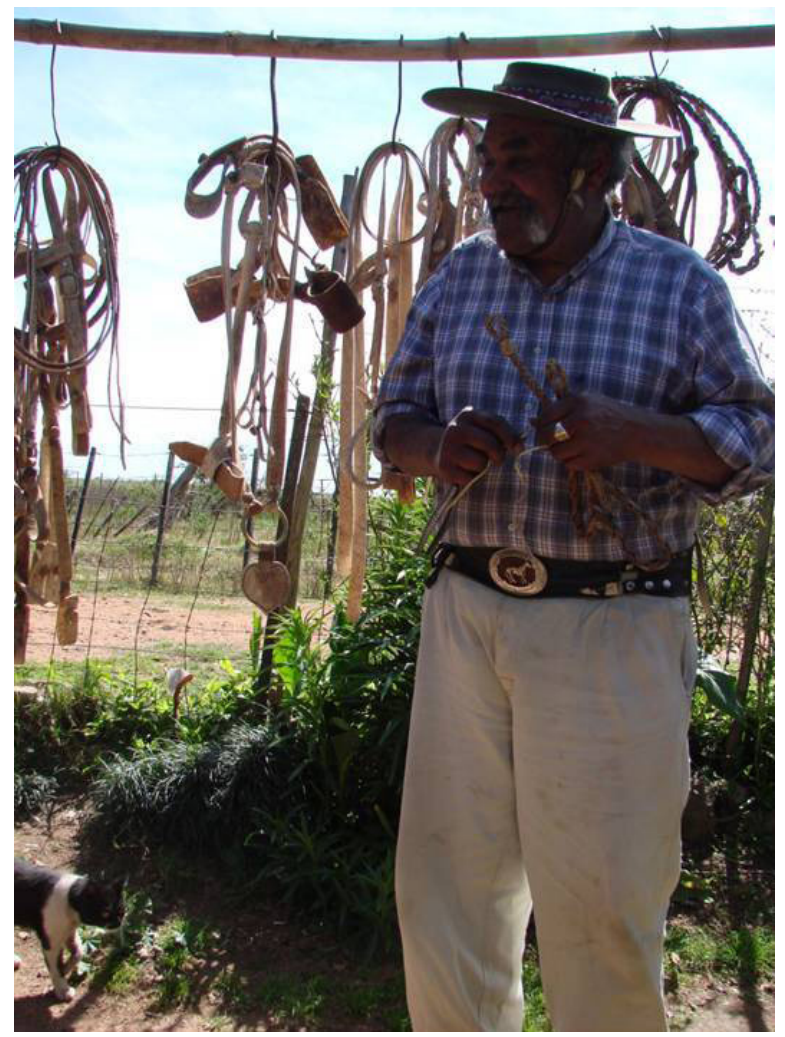

Figura 5 - Sr. Ginêz Costa, guasqueiro e campeiro, em frente ao seu rancho de moradia com artefatos em couro confeccionados e comercializados por ele para as lidas campeiras, Vila da Lata - Aceguá/RS. Foto: Marta B. Rodrigues Acervo INRC Lidas Campeiras da Região de Bagé/RS (2011).

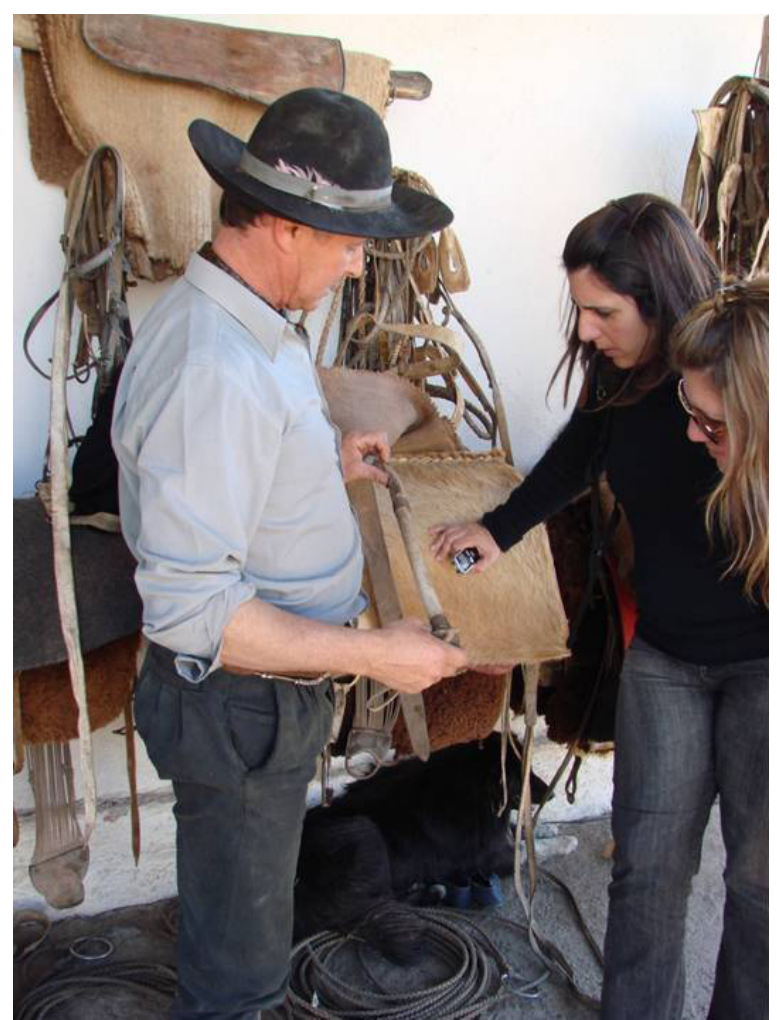

Figura 6-Minga Blanco apresentando à equipe os artefatos da lida campeira confeccionados por ele - Aceguá/RS. Foto: Marta B. Rodrigues - Acervo INRC Lidas Campeiras da Região de Bagé/RS (2011). 
Foi com essa visão que seguimos a rede de interlocutores (as) de forma a perceber o que os (as) conecta a partir dos diversos significados do patrimônio cultural e suas ressonâncias para o grupo. Sobre isso, entendemos que um patrimônio não depende apenas da vontade e decisão política de uma agência de Estado, nem apenas de uma atividade consciente e deliberada de indivíduos ou grupos; os objetos/artefatos que compõem um patrimônio precisam encontrar "ressonância" junto a seu público (BILHALVA \& RODRIGUES, 2017; GONÇALVES, 2005).

\section{A cultura campeira tornada visível}

É um modo de vida, tudo está relacionado, fazendo parte de um sistema; se afastar disso é complicado. (Flávia Blanco, proprietária rural e professora - Aceguá/Brasil).

A visão de mundo (ideias) das pessoas que compõe a rede nessa área cultural do pampa, bem como o ethos (valores) compartilhado por esses indivíduos (GEERTZ, 1989), refletem a realidade da lida campeira traduzida em criar, manter e reproduzir rebanhos de gado - principalmente ovino, equino e bovino - atividade desempenhada por meio dos vários ofícios entendidos como especialidades de determinados trabalhadores ${ }^{12}$, qualificados anteriormente como responsáveis pelas atividades de esquila, de doma, do tropeirismo, do alambrado, do pastoreio, da lida caseira e do guasqueiro, entre outros ofícios e trabalhos complementares. Enfatizamos que, embora se evidencie esses ofícios, citados assim, como especialidades de determinados trabalhadores, são, no entanto, abarcados pelo saber de um único (e múltiplo) agente, o campeiro ${ }^{13}$, aquele que conhece e sabe fazer um pouco de cada uma das lidas. (RIETH et al, 2013a). Os ofícios compõem um sistema que coloca em relevo diferentes temporalidades no momento em que entrelaça trabalho e modo de vida.

A medida em que etnografávamos as atividades, fomos percebendo se tratar de algo que o campeiro dominava na sua integralidade. A questão das especializações vem com as aptidões de alguns trabalhadores e também com a entrada da legislação trabalhista que formalizou os contratos de trabalho e definiu atividades, salários e jornadas. O conceito moderno de trabalho adentrou os campos pampeanos, entendidos como tradicionais na cosmologia de quem vive nesse ambiente, formalizando as práticas campeiras antes vistas como um saber viver e se relacionar com o ambiente. (SILVA, 2014).

O valor "trabalho" aparece, então, como norteador das práticas, advindo dos processos históricos de desenvolvimento. Consequentemente, foi se ajustando e se transformando no ritmo da vida cotidiana até chegar à categoria hoje entendida e percebida pela sociedade moderna como trabalho, especialidade ou ofício (SILVA, 2014). Essa última categoria é utilizada pelo IPHAN no INRC, para se referir aos saberes e modo de fazer.

Pela observação desses ofícios e sua inserção nas fichas destinadas à sua descrição, é possível compreender que as lidas traduzem um modo de vida, o qual coloca em relação e interação homens, mulheres, animais, objetos e paisagem (RIETH, RODRIGUES \& SILVA, 2015). E esta interação foi se tornando visível para a equipe de pesquisa quando adentrávamos o campo, vivenciávamos a cultura do "outro" e, sobretudo, quando preenchíamos as fichas. Para Roy Wagner "A cultura é tornada visível pelo choque cultural, pelo ato de submeter-se a situações que excedem a competência interpessoal ordinária e de objetificar a discrepância como uma entidade - ela é delineada por meio de uma concretização inventiva dessa entidade

\footnotetext{
${ }^{12}$ Utilizamos a palavra no masculino, pois a rede que se apresentou nas lidas campeiras foi praticamente formada por homens.

${ }^{13} \mathrm{O}$ termo campeiro refere-se à pessoa que vivencia ou já vivenciou os trabalhos realizados na empresa da pecuária extensiva com o intuito de criar, manter e reproduzir rebanhos de gado ovino, equino e bovino, no extremo meridional da América do Sul - realidade que mescla as fronteiras políticogeográficas entre o estado do Rio Grande do Sul e os países vizinhos, Argentina e Uruguai. (Kosby \& Rieth et al, 2012).
} 
após a experiência inicial (WAGNER, 2012, p. 37)”.

Seguindo a rede, enfatizando imaterialidade e materialidade, focamos na relação/interação entre elementos heterogêneos que a conformam (humanos e não humanos), localizando suas conexões, buscando não dicotomizar esses componentes e compreendendo sua realidade. Foi esta rede múltipla que nos forneceu o contexto interpretativo. (LATOUR, 2009)

As técnicas dos ofícios das sete lidas e atividades complementares, bem como as relações entre os elementos diversos envolvidos nessas lidas ressonam, através dos objetos e das práticas, diretamente nas subjetividades dos sujeitos, constituindo-os. Esse aspecto fica evidente diante dos relatos sobre lidas "brabíssimas":

Peões descrevem o universo desta lida como árduo, perigoso, insalubre. No entanto, essas mesmas agruras parecem trazer os atributos ontológicos necessários à construção desses homens como pessoas - e mesmo imprescindíveis à manutenção de sua existência. Acordar antes de raiar o sol e ter que quebrar geada com a sola do pé descalço, derrubar novilhos com o próprio corpo (pois a contenção com o laço pode fraturar o animal), correr risco de morte ante a fúria de um touro, participar do mesmo ambiente que animais peçonhentos, enfrentar temporal no meio do campo aberto para salvar filhotes do rebanho, domar cavalo xucro, são alguns aspectos apontados como responsáveis pelo fato de serem "brabíssimas" as lidas campeiras- o que, no entanto, não chega a representar uma potência negativa, visto que, pelo contrário, o controle dessas situações impostas pelas forças da natureza selvagem, incorporado, é claro, pela exploração capitalista de sua força de trabalho, tem agência construtora dos sujeitos (RIETH, RODRIGUES \& SILVA, 2015, p. 180).

As narrativas que incidem nas construções dos sujeitos campeiros são múltiplas, mas com alguns elementos recorrentes. O cavalo é um aliado na constituição desses homens, o trabalho e a juventude também determinam, de certa maneira, as masculinidades:

Eu trabalho em estância (capataz), eu cuido de uma estância, só que agora estou com um problema num braço, eu há muito tempo sofri um acidente no serviço mesmo, e com o passar do tempo foi evoluindo [...] então isso que está me afastando de trabalhar. Mas como eu sou da lida, eu e meu parceiro aqui alugamos isso [cocheira para cavalo na cidade de Bagé] para estar envolvido com os cavalos, eu gosto de andar a cavalo e lidar com os bichos [...] e não fico em casa, porque se eu ficar em casa no dia a dia eu vou a loucura. É só para nós estar aqui, chega um conversa um pouco, dá vontade de tomar um mate nós vamos ali fazer, nós almoçamos junto aí e estamos no dia a dia, porque eu não sei se eu sei viver sem o cavalo, nem que seja para ficar olhando no dia a dia. (Seu Beto, ex-trabalhador rural - Bagé, 2012).

A lida obrigava a gente a ser gente, a ser campeiro, o homem do campo é extremamente educado e disciplinado, porque teve essa formação de pai, mais rígida. [...] O cavalo mantém o vínculo com o campo. Esse contato com o cavalo é o vínculo que te leva ao campo. Tirou o cavalo do gaúcho e ele não é mais nada. (Eliezer - proprietário rural, poeta e professor aposentado -Bagé, 2012). 
As falas das mulheres também carregam essa construção das subjetividades alicerçada nas lidas. Elas não estão presentes no trabalho considerado mais duro no campo, mas fazem parte das atividades no entorno das casas e, em alguns casos, na administração das propriedades: "Eu gosto de viver aqui, acordar cedo, fazer o fogo, colocar a água pro mate, essa é a hora que a gente conversa, se organiza pro dia. Tenho a minha horta, fico aqui horas e horas depois do trabalho" (Flávia Blanco, proprietária rural e professora- Aceguá, 2013). “Ah, se eu pudesse voltava para o campo, ficar perto dos bichos, eu sinto falta disso" (Esposa de capataz, empregada das “casas” da estância, hoje vive na cidade de Bagé, 2013).

Os vários elementos que constituem a vida no campo, o fogo (figura 7), o couro como matéria prima da maioria dos artefatos para o trabalho campeiro, as vestimentas, os objetos e a paisagem vasta do pampa (figura 8) também atuam nessa construção da subjetividade. São elementos indissociáveis da lida campeira que se estendem para outras dimensões. O fogo, presente no galpão, tem uma função utilitária de aquecer a água para o chimarrão, assar a carne, cozinhar a comida e aquecer o ambiente no frio do inverno. Fora do galpão, também funciona para aquecer o ferro para a marcação dos animais e também para a confecção de ferraduras, marcas para gado e etc.

Entretanto, a dimensão funcional constitui-se somente como uma de suas funções; ele - o fogo - tem função simbólica, informa algo para os sujeitos e, consequentemente, age sobre eles. Reunir-se na volta do fogo, ou até conversar com ele (como muitas vezes ouvimos) tem um valor fundante nessa cultura. Ele remete à sociabilidade, e viver sem o fogo traz sofrimento e solidão, vejamos as narrativas de Seu Nelson e Seu Beto: "O que eu mais sinto falta na cidade é o fogo, ficar na volta do fogo. Isso é o mais difícil” (Seu Nelson - Bagé/2012). “O fogo fica sempre aceso aqui, isso é muito importante para o gaúcho. Aqui fazemos nossa comida, esquentamos a água para nosso mate e sentamos na volta para prosear” (Seu Beto Bagé/2012).

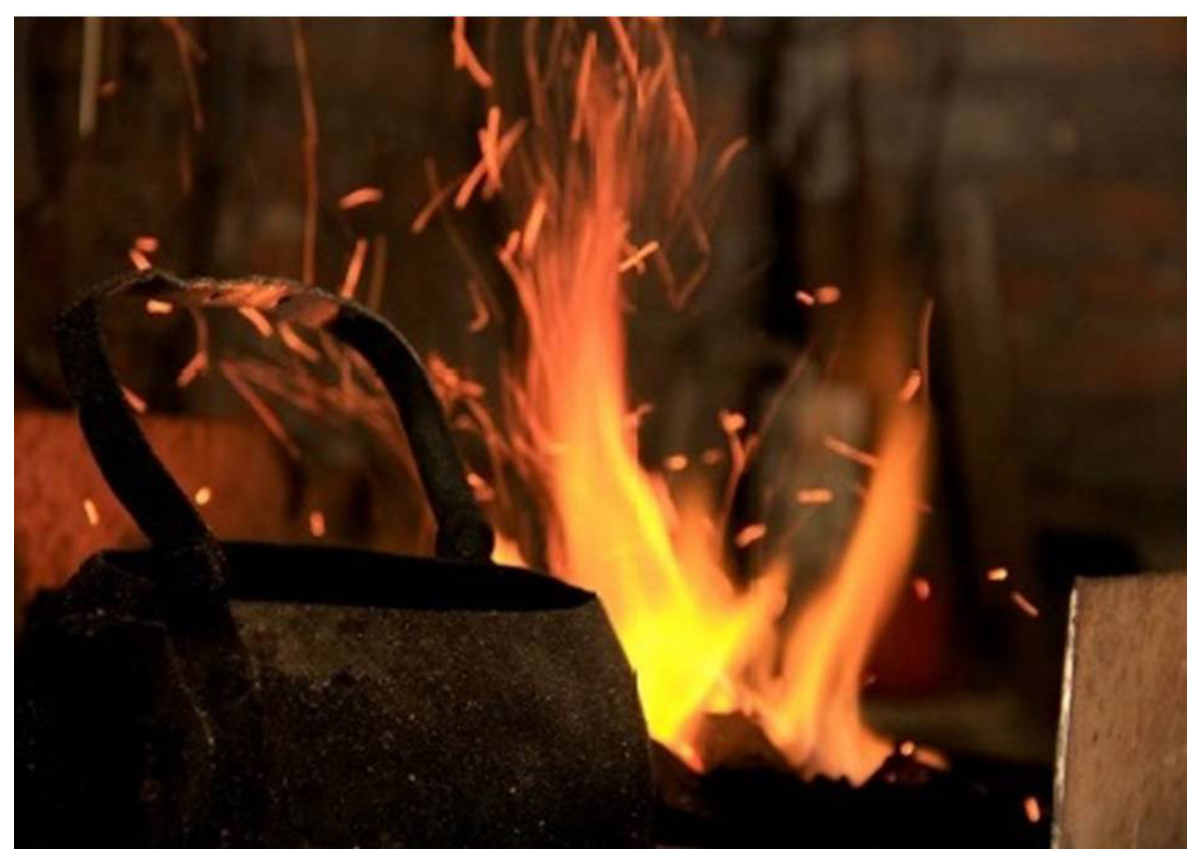

Figura 7 - Chaleira de ferro aquecendo água para o mate em fogo de chão - Bagé/RS. Foto: Acervo INRC Lidas Campeiras da Região de Bagé/RS (2012). 


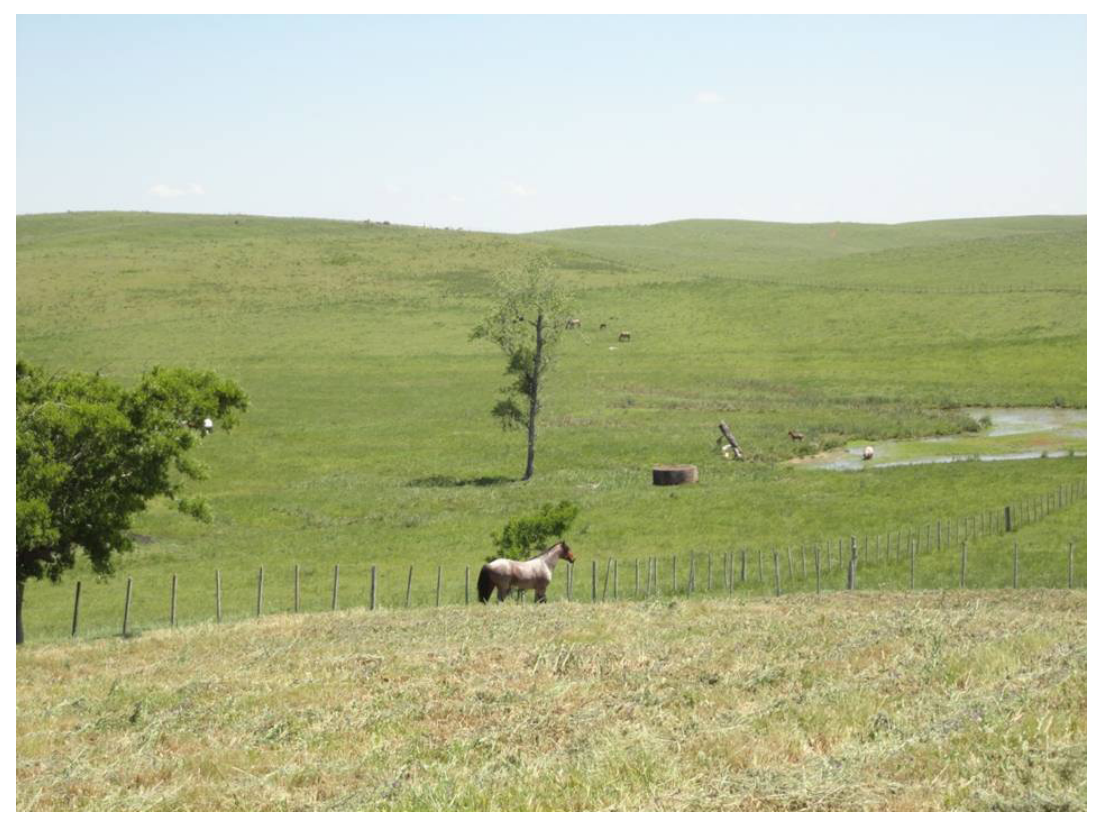

Figura 8 - Paisagem típica do pampa sul-riograndense: cavalos, cercas de alambrados, uma aguada (açude) e a vastidão dos campos. Estância Santa Leontina - Aceguá/RS. Foto: Marta B. Rodrigues - Acervo INRC Lidas Campeiras da Região de Bagé/RS (2011).

O movimento que as coisas fazem no modo de vida campeiro, parecem entrar em um ritmo circular: um exemplo são os artefatos feitos em couro para as lidas. Geralmente confeccionados ou remendados/consertados pelos próprios campeiros nos dias de chuva ou nas horas de descanso dentro das estâncias, os apetrechos usados no trabalho do campo têm como matéria prima o couro, que é retirado do animal após o abate e tratado. Esse couro volta aos animais no momento em que é parte primordial de um laço, ou rebenque ${ }^{14}$, por exemplo, e é usado para laçar um bovino (laço) ou para fazer o cavalo apurar o passo (rebenque). Esses artefatos extrapolam sua função utilitária, ao passo que também são percebidos pelo grupo cultural como uma arte - o ofício do guasqueiro, artesão responsável pela confecção dos artefatos de forma profissional ou amadora, é valorizado como um saber fundamental para o modo de vida campeiro. Nesse ofício, sempre é enfatizada a habilidade, o capricho e a beleza necessária para a confecção do artefato. Além de ser funcional, tem que estar “bem feito". Há um prazer e orgulho por parte dos campeiros em mostrar seu trabalho, sua arte, tanto no contexto do campo como em outros. Para os campeiros que estão fora do ambiente rural, trançar o couro significa uma conexão com a vida no campo e com as lidas campeiras, como nos fala um dos interlocutores: Eu não sei se vou ter pra quem deixar [o saber do guasqueiro], mas representa uma continuação do que meu vô e meu pai faziam. Isso é a única coisa que liga o gaúcho da cidade ao campo (Abelardo - guasqueiro em Pelotas-2013). O pampa, com sua paisagem, edificações, artefatos, animais, plantas, sujeitos informam territórios de existência. Bota, chapéu, bombacha e lenço acompanham os sujeitos masculinos e femininos desta região para além do trabalho no campo, fazem parte da indumentária do ser campeiro e assim os identifica como tal - seres cavaleiros que trabalham com rebanhos na região do pampa sul-rio-grandense. Essa noção é trazida a partir da ideia de que não existem fronteiras fixas para o campeiro, o "Sul” como área etnografada e etnografável ultrapassa os limites geográficos e políticos brasileiros e adentram Uruguai e Argentina (LEAL, 1997).

A cultura pampeana trazida no inventário, portanto, é construída a partir de conceitos discutidos pela historiografia

\footnotetext{
${ }^{14}$ Um tipo de chicote típico da lida campeira, usado tanto no Rio Grande do Sul, como em países vizinhos do Brasil com uma cultura campeira similar (Argentina, Uruguai, Chile...).
} 
e antropologia no que tange à configuração de um ethos delimitado por relações entre humanos e não humanos em diversas dimensões (paisagem, artefatos, animais, etc.). Essas dimensões somente foram acessadas pela equipe de pesquisa pela configuração interdisciplinar que constituiu nosso olhar, ouvir e escrever, e, sobretudo, o método etnográfico que nos colocou em relação com o "outro", aliada à metodologia INRC que privilegia essa perspectiva totalizante da cultura, possibilitando-nos a localizar e compreender as lidas campeiras como referências culturais compartilhadas pelos grupos habitantes da região do pampa sul-rio-grandense.

\section{CONSIDERAÇÕES FINAIS}

Ao contrário dos patrimônios biológicos que constituem o ser humano como espécie - um, endógeno (diversidade genética) e um, exógeno (cuja gestão lhe atribui, mas que não lhe pertence, constituído pela biodiversidade), passíveis de conservação e transmissão direta, o patrimônio cultural dependente do aprendizado e transmissão do conhecimento geracional. Ainda que seja um patrimônio herdado, ele é vivido e, portanto, está em constante transformação (PRATS, 1998).

As culturas não seguem um modelo engessado na transmissão, pois existe uma arte criativa que é acionada pelos sujeitos culturais com o passar do tempo. Assim, o que se pode conservar em uma cultura é o conhecimento, aquilo que a humanidade pode preservar e transmitir, que pode ser entendido como patrimônio cultural.

Tanto el conocimiento de los logros científicos y artísticos más singulares, como el conocimiento de los sistemas e artilugios culturales que han permitido al hombre em situaciones ecológicas muy diversas y em situaciones sociohistóricas muy cambiantes, adaptarse a la vida en el planeta y a la convivência con sus semejantes (PRATS, 1998, p. 73).

É evidente, no entanto, que não se pode conservar/preservar o conhecimento absoluto das culturas, por serem realidades sistemáticas e cambiantes. Portanto, o que se pretendeu indicar como referências culturais no Inventário das Lidas Campeiras é parte desse conhecimento totalizante, segundo critérios valorativos e ideológicos compartilhados no tempo presente (CARNEIRO DA CUNHA, 2005; PRATS, 1998). Os conhecimentos que buscamos nos processos que compõem a cultura pesquisada estão fundamentados no sentimento de continuidade em relação às gerações anteriores, com ofícios e práticas enraizados no cotidiano dos sujeitos culturais do presente, constituindo territórios de significados de um modo de vida que tem a sua própria ruína como a base de sua descrição/invenção. A ruína entendida aqui como as transformações pelas quais o mundo dessa pecuária passa ao longo dos anos, e não como o fim de uma cultura (KOSBY \& RIETH, 2012; SILVA, 2014; WAGNER, 2010).

Com essa percepção, centramos nossos olhares no processo da cultura, que se transforma toda vez que outros elementos são apresentados. Mostrar a ressonância nas subjetividades das pessoas e, consequentemente, a visibilização de referências culturais, foi o objetivo do INRC Lidas Campeiras na Região de Bagé, possibilitada pela interdisciplinaridade a que se propôs a investigação a participação de pessoas em processos de formação, profissionais de áreas diversas e as comunidades envolvidas. Diante disso, a ciência parece ser o lugar legitimado para formalizar novos conhecimentos, propor novas interpretações e significados, e restabelecer novos repertórios culturais. Dessa maneira, cultura e ciência emergem como uma soma de invenções e conquistas (PRATS, 1998; WAGNER, 2010). Patrimônios culturais imateriais resultam desse encontro, das conexões dessas invenções com as instituições que os legitimam, tornando-se vivos quando seu caráter processual e dinâmico passa a ser observado. 


\section{REFERÊNCIAS}

ANJOS, Flávio S. O futuro ameaçado: o mundo rural face aos desafios da masculinização, do envelhecimento e da desagrarização. Ensaios FEE, v. 26, n. 1, p. 661-694, 2005.

APPADURAI, Arjun. A vida social das coisas: as mercadorias sob uma perspectiva cultural. Niterói: Editora da Universidade Federal Fluminense, 2008.

BILHALVA, Liza; RODRIGUES, Marta B. Artefatos como suportes de memória na construção da masculinidade no Pampa Sul-Riograndense. Tessituras: Revista de Antropologia e Arqueologia, v. 5, n. 2, p.113-141, 2017.

BOAS, Franz. Antropologia cultural (org. Celso Castro). Rio de Janeiro: Jorge Zahar Ed. 2005.

BOURDIEU. Pierre. A dominação Masculina. Rio de Janeiro: Bertrand Brasil. 1999.

CARDOSO DE OLIVEIRA, Roberto. O trabalho do antropólogo. $2^{\mathrm{a}}$ Ed, Brasília: Paralelo 15; São Paulo: Editora Unesp, 2006.

CARNEIRO DA CUNHA, Manuela. Introdução. Revista do Patrimônio Histórico e Artístico Nacional: Patrimônio imaterial e biodiversidade. v. 32, p. 15-27, 2005.

CONNEL, Robert W. Políticas da Masculinidade. Educação e Realidade. v. 20, n. 2, p. 185-206, 1995.

FILHO, Manuel F. L.; ABREU. Regina M. R. M. A antropologia e o patrimônio cultural no Brasil. In: FILHO, Manuel F. L. et al (org). Antropologia e Patrimônio Cultural: diálogos e desafios contemporâneos. Blumenau: Nova Letra, 2007, p. 21-43.

FREIRE, Beatriz M. O Inventário e o Registro do Patrimônio Imaterial: novos instrumentos de preservação. Cadernos do LEPAARQ - Textos de Arqueologia, Antropologia e Patrimônio. Editora da Universidade Federal de Pelotas, v. 2 , n. 3, p. 11-20, 2005.

FUNARI. Pedro P.; PELEGRINI, Sandra C. A. Patrimônio Histórico e Cultural. $2^{\text {a }}$ Ed, Rio de Janeiro: Jorge Zahar Ed., 2009.

GEERTZ, Clifford. A interpretação das culturas. Rio de Janeiro: LTC, 1989.

GONÇALVES, José Reginaldo S. O patrimônio como categoria de pensamento. In: ABREU. Regina; CHAGAS, Mário (org). Memória e patrimônio: ensaios contemporâneos. Rio de Janeiro: DP\&A, ,2003, p. 25-33.

. Ressonância, materialidade e subjetividade: as culturas como patrimônios. Horizontes Antropológicos, Porto Alegre, v. 11, n. 23, p. 15-36, 2005.

. Os limites do patrimônio. In: FILHO. Manuel F. L. et al (org). Antropologia e Patrimônio Cultural: diálogos e desafios contemporâneos. Blumenau: Nova Letra, 2007, pp. 239-248.

INSTITUTO DO PATRIMÔNIO HISTÓRICO E ARTÍSTICO NACIONAL (IPHAN). Inventário Nacional de Referências Culturais: Manual de aplicação. Brasília: IPHAN, 2000. Patrimônio Cultural Imaterial: para saber mais. Ed. Brasília: IPHAN, 2012.

.Livros de Registros. Disponível em < http://portal.iphan.gov.br/pagina/detalhes/122> Acessado em: 08/jul/2017.

KOSBY, Marília F.; SILVA, Liza B. M. INRC - Bagé: sobre atualizações da cultura gaúcha a partir do inventário do sistema 
da pecuária no sul do Rio Grande do Sul. Revista Perspectivas Sociais. Pelotas: Programa de Pós-Graduação em Sociologia da UFPel, v. 2, n. 1, p. 2-14, 2013.

LATOUR, Bruno. Jamais Fomos Modernos. Rio de Janeiro: Ed.34, 2009.

LEAL, Ondina. Honra, morte e masculinidades na cultura gaúcha. Antropologia do Corpo e da Saúde I. Cadernos de Antropologia. v. 5, p. 7-22, 1992.

. The gauchos: male culture and identity in the Pampas. Tese (Doutorado em Antropologia). Berkeley: University of California, 1989.

. Do etnografado ao etnografável: "O Sul” como área cultural. Horizontes Antropológicos. Porto Alegre: Programa de Pós-Graduação em Antropologia Social da Universidade Federal do Rio Grande do Sul, v. 3, n. 7, p. 201-214, 1997.

MAUSS. Marcel. Sociologia e Antropologia. São Paulo: Cosac Naify, 2003.

PALM, Juliano L.; KONRAD, Diorge A. O mundo do trabalho rural no Rio Grande do Sul no Estado Novo (1937-1945): Um questionamento da "Harmonia social". Revista do Corpo discente do PPGH/UFRGS, v. 2, n. 4, p. 286-296, 2009.

POULOT, Dominique. Um Ecossistema do Patrimônio. In: CARVALHO, Cláudia. S. R. et al (orgs.). Um Olhar Contemporâneo sobre a Preservação do Patrimônio Cultural Material. Rio de Janeiro: Museu Histórico Nacional, 2008, p. 26-43.

PRATS, Llorenç. El Concepto de Patrimonio Cultural. Política y Sociedad, v. 27, p. 63-76, 1998.

RIETH, Flávia; KOSBY, Marília F.; SILVA, Liza B. M.; RODRIGUES, Marta B.; DOBKE, Pablo R.; LIMA, Daniel V. Inventário Nacional de Referências Culturais - Lidas Campeiras na Região de Bagé - Volume 1. Pelotas: Complexo Criativo Flor de Tuna, 2013a.

RIETH, Flávia; KOSBY, Marília F.; SILVA, Liza B. M.; RODRIGUES, Marta B.; DOBKE, Pablo R.; LIMA, Daniel V. Inventário Nacional de Referências Culturais - Lidas Campeiras na Região de Bagé - Volume 2. Pelotas: Complexo Criativo Flor de Tuna, 2013b.

RIETH, Flávia; KOSBY, Marília F.; SILVA, Liza B. M.; RODRIGUES, Marta B.; DOBKE, Pablo R.; LIMA, Daniel V. Inventário Nacional de Referências Culturais - Lidas Campeiras na Região de Bagé - Volume 3. Pelotas: Complexo Criativo Flor de Tuna, 2013c.

RIETH, Flávia M. S.; RODRIGUES, Marta B.; SILVA, Liza B. M. As lidas campeiras na região de Bagé/RS: sobre as relações entre homens, mulheres, animais e objetos na invenção da cultura campeira. In: NUMMER, Fernanda V.; FRANÇA, Maria Cristina C. C (Org.). Entre oficios e profissões: reflexões antropológicas. Belém: GAPTA/ UFPA, 2015. p. 175-195.

SANT'ANNA. Márcia. A face imaterial do patrimônio cultural: os novos instrumentos de reconhecimento e valorização. In: ABREU. Regina; CHAGAS, Mário (org). Memória e patrimônio: ensaios contemporâneos. Rio de Janeiro: DP\&A, p. 49-58, 2003.

SANTOS, Milton. A natureza do espaço: Técnica e tempo, razão e emoção. São Paulo: Ed.USP, 2002.

SILVA, Liza B. M. Masculinidade, memória e trabalho: um estudo etnográfico com homens campeiros do pampa sul-riograndense em processos de mobilidade. Tessituras: Revista de Antropologia e Arqueologia. Pelotas, v. 1, n. 1, p. 123-149, 2013. 
SILVA, Liza Bilhalva. M. Etnografando patrimônios: os reflexos de uma formação em antropologia social e cultural a partir da experiência em um Inventário Nacional de Referências Culturais. Trabalho de Conclusão de Curso (Graduação em Antropologia Social e Cultural). Universidade Federal de Pelotas, Pelotas, 2014.

THOMAS, Julian. A materialidade e o social. Revista do Museu de Arqueologia e Etnologia, São Paulo, v. 3, p. 15-20, 1999.

VAN VELTHEM, Lucia H. Farinha, casas de farinha e objetos familiares em Cruzeiro do Sul (Acre). Revista de Antropologia, São Paulo, v. 50, n. 2, p. 605-631, 2007.

WAGNER, Roy. A invenção da cultura. São Paulo: Cosac Naify. 2010.

\section{REGISTROS ORAIS}

Entrevistas com interlocutoras e interlocutores da pesquisa do INRC - Lidas Campeiras na Região de Bagé (RIETH et al., 2013a, 2013b, entre os anos 2010 e 2013. 